\title{
NOTICE REQUIREMENT IN WARRANTY ACTIONS INVOLVING PERSONAL INJURY
}

I

\section{NOTICE UNDER THE UNIFORM SALES ACT}

Section 49 of the Uniform Sales Act provides that the acceptance of goods does not preclude a buyer's recovery against the seller for breach of warranty; but, "if ... the buyer fails to give notice to the seller of the breach of any promise or warranty within a reasonable time after the buyer knows, or ought to know of such breach, the seller shall not be liable therefor." ${ }^{1}$ Numerous decisions in favor of the seller, wholly due to the lack of seasonable notice, illustrate the significance of the requirement. ${ }^{2}$ Since section 49 is phrased in terms "buyer" and "seller,"3 an important question regarding notice arises where the warranty action lies between parties not in privity to the contract of sale. Is the notice requirement of sufficient importance that courts should extend its applicability beyond the technical purview of the Sales Act? This Comment examines this and other problems of statutory notice, with particular reference to the recent Cahfornia Supreme Court decision in Greenman v. Yuba Power Products, Inc.4

At common law some jurisdictions held that the mere acceptance of goods released the seller from any liability for defects in quality. ${ }^{5}$ When the Sales Act ameliorated this larsh rule, the seasonable notice requirement was inserted to provide the seller with some protection against belated claims. ${ }^{6}$ To constitute

1 CaL. Crv. CODE $\$ 1769$. The Uniform Sales Act is currently the law in 23 states, the District of Columbia, and the Panama Canal Zone. These jurisdictions and their respective statutes are listed in 1 U.L.A. (Supp. 1962, at 7-8). The Uniform Commercial Code, which has been enacted by the legislatures of 19 states, contains a substantially similar notice provision. The notice section of the Code provides that "the buyer must within a reasonable time after he discovers or should have discovered any breach notify the seller of breach or be barred from any remedy. ..." UNIFORM COMDMERCIAL CODE \$2-607. See note 51 infra, for a list of the states that have adopted the Commercial Code.

2 E.g., Adler v. United States, 270 F.2d 715 (8th Cir. 1959); Smith v. Pizitz of Bessemer, Inc., 271 Ala. 101, 122 So. $2 d 591$ (1960); Ice Bowl, Inc. v. Spalding Sales Corp., 56 Cal. App. 2d 918, 133 P.2d 846 (1943).

3 UNIFORAS SALES ACT $\& 76$ provides, in part:

(1) In this act, unless the context or subject matter otherwise requires-...

"Buyer" means a person who buys or agrees to buy goods or any legal successor in interest of such person. ...

"Seller" means a person who sells or agrees to sell goods, or any legal successor in the interest of such person.

459 A.C. 67, 377 P.2d 897, 27 Cal. Rptr. 697 (1963).

6 E.g., Jones v. McEwan, 91 Ky. 373, 16 S.W. 81 (1891); Rosenfield v. Swenson, 45 Minn. 190, 47 N.W. 718 (1891); Reed v. Randall, 29 N.X. 358 (1864). See generally Vord, SAres 460-61 (2d ed. 1959). In other states acceptance did not bar a subsequent action for defects in quality. Graff v. D. M. Osborne \& Co., 56 Kan. 162, 42 Pac. 704 (1895); Wallace v. L. D. Clark \& Son, 74 Okla. 208, 174 Pac. 557 (1918).

${ }^{6} \mathrm{~A}$ rule seems desirable which is capable of some certainty in its application and also on the one hand avoids the hardship on the buyer of holding that acceptance ... necessarily deprives hin of the seller's obligations, and on the other hand avoids the hardship on the seller of allowing a buyer at any time within the period 
adequate notice the buyer must fairly apprise the seller that he plans to hold him responsible for the damage incurred, ${ }^{7}$ or at least such conclusion must be inferrable from the buyer's conduct. ${ }^{8}$ Moreover, notice must be given within a reasonable time. Most of the litigation involving notice has centered around the determination of "reasonable time."

Timeliness has often proved to be of particular importance when the defective goods inflict personal injury upon the consumer. Although notice is accepted as a sound commercial practice, ${ }^{10}$ it is frequently criticized when applied to injured consumers "not . . . steeped in the 'business practice' which justifies the rule."11 Nevertheless, the language of the notice section is quite broad, and courts have

of the Statue of Limitations to assert that the goods were defective, though no objection was made when they were received. With this in mind the positive requirement of prompt notice was inserted in the statute.

Witurston, SAIEs $\$ 484 a$, at 38 (rev. ed. 1948).

While this may be one purpose of the notice requirement, it is not the only purpose. As Judge Learned Hand stated, "the purpose of the notice is to advise the seller that he must meet a claim for dainages, as to which, rightly or wrongly, the law requires that he shall have early warning." American Mfg. Co. v. United States Shipping Board Emergency Fleet Corp., 7 F.2d 565, 566 (2d Cir. 1925).

7 Texas Motorcoaches v. A.C.F. Motors Co., 154 F.2d 91 (3d Cir. 1946) ; Jones v. Burgermeister Brewing Corp., 198 Cal. App. 2d 198, 18 Cal. Rptr. 311 (1961) ; Hellenbrand v. Bowar, 16 Wis. 2d 264, 114 N.W.2d 418 (1962) (dictum). Commencement of a suit for breach of warranty, Arata v. Tonegato, 152 Cal. App: 2d 837, 314 P.2d 130 (1957), knowledge of the seller that a breach has occurred, Marsh Wood Products Co. v. Babcock \& Wilcox Co., 207 Wis. 209, 140 N.W. 392 (1932), and coinplaints to the seller that the goods are defective, Silvera v. Broadway Dep't Store, 35 F. Supp. 625 (S.D. Cal. 1940), have all been held insufficient as notice under the Sales Act.

8 United States v. Whitin Mach. Works, 79 F. Supp. 351, 358 (D.C. Mass. 1948), rev'd on other grounds, 175 F.2d 504 (1st Cir. 1949); Barni v. Kutner, 45 Del. 550, 558, 76 A.2d 801,805 (1950). The Conimercial Code, however, probably requires only that the notification inform the seller that the transaction may involve a breach. No claim for damages or threatened litigation is necessary. UNIFORMI COMAMERCIAI CODE § 2-607, comment 4, para. 2.

Even proper notifieation does not end the buyer's burden, for notice must be adequately pleaded in his complaint. Vogel v. Thrifty Drug Co., $43 \mathrm{Cal} .2 \mathrm{~d} 184,272$ P.2d 1 (1954). But see, Pritchard v. Liggett \& Myers Tobacco Co., 134 F. Supp. 829, 831-32 (W.D. Pa. 1955). In Title Ins. \& Trust Co. v. Affiliated Gas Equipment, Inc., 191 Cal. App. 2d 318, 12 Cal. Rptr. 729 (1961), the court cast doubt upon the significance of Vogel v. Thrifty Drug Co., supra, by holding that leave to amend must be granted, if the failure to plead notice adequately does not prejudice the manufacturer.

${ }^{9}$ See generally 1 Fronar \& FrIEdman, Products Liabutity \& 19.05 [2] (1961).

This question generally is one to be answered from the particular circuinstances of each case, e.g., Pritchard v. Liggett \& Myers Tobacco Co., suppra note 8 , and its determination is normally a function of the jury, e.g., Whitfield v. Jessup, 31 Cal. 2d 826, 193 P.2d 1 (1948). Where the facts surrounding the notice, however, are undisputed and admit of only a single inference, the courts have decided the issue as a matter of law. E.g., Davidson v. Herring-Hall Marvin Safe Co., 131 Cal. App. 2d 874 (Los Angeles Super. Ct. 1955); Necho Coal Co. v. Denise Coal Co., 387 Pa. 567, 128 A.2d 771 (1956). Some courts decide the question as a matter of law even though niore than one inference can be drawn from the undisputed facts. Hazelton v. First Nat'l Stores, 88 N.H. 409, 190 Atl. 280 (1937).

10 See 3 WILITSTON, SALES $\S 484$ (rev. ed. 1948).

112 HARPER \& J ANIES, ToRTS $\$ 28.17$ at 1575 (1956). A similar view is adopted in 1 Fruarer \& Friedman, Products IIabintry 537 (1961). On the other hand, Dean Prosser appears to limit his dislike of the notice requirement to situations in which there are both "personal injuries, and notice to a remote seller." Prosser, The Assault Upon the Citadel (Strict Liability to the Consunter), 69 YALE L.J. 1099, 1130 (1959). 
consistently held it applicable in cases involving personal injury. ${ }^{12}$ Rather than construe the statute as inapplicable in such actions, the courts have often resorted to safeguarding the injured consumer by extending the "reasonable" time far beyond its normal commercial length. ${ }^{13}$

The strain on the requirement of notice, as applied to personal injury cases, seems destined to continue and increase as more jurisdictions break away from a requirement of privity of contract in warranty cases. ${ }^{14}$ Since the notice section of the Sales Act is couched in the terms "buyer" and "seller," it would seem technically inapplicable when there is no privity of contract between the parties

12 In Smith v. Pizitz of Bessemer, Inc., 271 Ala. 101, 122 So. 2d 591 (1960), the court held that "there is nothing in the statute which indicates that the notice provision was intended ... to limit the application of the provision to commercial situations alone and makes no disinction between a situation where the purchaser suffers a monetary loss in a commercial transaction rather than a personal injury." Id. at 103,122 So. $2 \mathrm{~d}$ at 593 ; accord, Whitfield v. Jessup, 31 Cal. 2d 826, 193 P.2d 1 (1948) (undulant fever from raw cream); Hazelton v. First Nat'l Stores, 88 N.H. 409, 190 Atl. 280 (1937) (trichinosis froin diseased pork chops); Owen v. Sears, Roebuck \& Co. 273 F.2d 140 (9th Cir. 1959) (severe burns due to ignited shirt). New York appears to be the only jurisdiction that has actually held the requirement of notice to be inapplicable because personal injuries are involved. Kennedy v. F. W. Woolworth Co., 205 App. Div. 648, 200 N.Y.S. 121 (1923).

13 In Whitfield v. Jessup, 31 Cal. 2d 826, 193 P.2d 1 (1948), the court reversed a nonsuit against a plaintiff consumer who had contracted undulant fever from raw cream purchased by her from the defendant. Although she gave no notice until nine months after she became ill, and five months after the cause was definitely ascertained, the court held that "what constitutes a reasonable time where the goods sold are foods containing latent defects, which are immediately consumed, presents a different question than does the ordinary sale where the article is subject to examination and use which will reveal its defect. . . . The case must be controlled by its special circumstances." Id. at 832, 193 P.2d at 4. Other courts have recognized an extended time for giving notice in personal injury cases where the long delay does not prejudice the seller. Pritchard v. Liggett \& Myers Tobacco Co., 295 F.2d 292 (3d Cir. 1961); Bonker v. Ingersoll Products Corp., 132 F. Supp. 5 (D. Mass. 1955). But see, Murphy v. Gilchrist Co., 310 Mass. 635, 39 N.E.2d 427 (1942), where a delay of only forty days in giving notice in a personal mjury action was held unreasonable as a matter of law.

The comment to the Uniform Commercial Code also takes the position that an injured consumer is to be judged by a different standard than a commercial buyer. UNIFORAC COAsMERCTAL CODE $\$ 2-607$, comments 4 and 5.

14 Liability has been imposed upon manufacturers, distributors, and retailers of defective goods who have had no contractual dealings with the injured consumers. E.g., Klein v. Duchess Sandwich Co., 14 Cal. 2d 272, 93 P.2d 799 (1939) (retailer); Patterson v. George H. Weyer, Inc., $189 \mathrm{Kan}$. 501, 370 P.2d 116 (1962) (distributor); Spence v. Three Rivers Builders \& Masonry Supply Inc., 353 Mich. 120, 90 N.W.2d 873 (1958) (manufacturer). Such exceptions to the rule are found mainly in cases involving foodstuffs, e.g., Crystal Coca-Cola Bottling Co. v. Cathey, 83 Ariz. 163, 317 P.2d 1094 (1957), and products for intimate bodily use, e.g., Gottsdanker v. Cutter Laboratories, 182 Cal. App. 2d 602, 6 Cal. Rptr. 320 (1960) (vaccine). An increasing number of courts similarly have rejected privity in cases perhaps best characterized as involving defective products capable of causing foresceable bodily harm. B. F. Goodrich Co. v. Hammond, 269 F.2d 501 (10th Cir. 1959) (automobile tires); MicQuaide v. Bridgeport Brass Co., 190 F. Supp. 252 (D. Conn. 1960) (insecticide spray); Henmingson v. Bloomfield Motors, 32 N.J. 358, 161 A.2d 69 (1960) (automobile).

Although the effect of these decisions has been to inpose strict liability sounding seemingly in tort, most courts lave persistently adhered to the application of Sales Act provisions. These courts bave either ignored the incongruity, Henningson v. Bloomfield Motors, supra, or utilized various devices to find a contractual basis where none exists. Maecherlein v. Sealy Mattress Co., 145 Cal. App. 2d 275, 302 P.2d 331 (1956) (express warranty derived from advertising and label on the product); Coca-Cola Bottling Works v. Lyons, 145 Miss. 876, 111 So. 305 (1927) (warranty running with the goods); Jeffery v. Hanson, 39 Wash. 2d 885, 239 P.2d 346 (1952) (third party beneficiary). 
to the litigation. Nevertheless, some courts have assumed without explanation that notice is essential to recovery in any warranty action, even though the parties are not "buyer" and "seller." 15 This apparent disregard for the wording of the section is probably due to a judicial feeling that a warranty action, although without privity, still hes basically in contract, thus making notice a proper requirement to be apphed. 16

On the other hand, a small number of decisions have rejected the need for notice where there is no privity of contract between the hitigants. The forerunner was a Washington case, La Hue v. Coca-Cola Bottling, Inc., ${ }^{17}$ in which the court held a manufacturer liable to a remote consumer under a comon law implied warranty of wholesomeness, "arising upon principles of tort." The notice provision was held to be inapphicable because the action was not between a "buyer" and "seller" under the Sales Act. ${ }^{18}$ The court did not consider the propriety of engrafting a notice requirement outside of the Sales Act, ${ }^{19}$ but may have impliedly rejected such a possibility because of the pure tort nature of the liability. In a subsequent decision, Chapman v. Brown, ${ }^{20}$ the federal district court sitting in Hawai held that an injured non-buyer had given notice to the defendant retailer within a reasonable time. As an alternative basis for its decision, the court stated that "an even better view would be that the 'notice provision of the act is inapplicable at least where personal injuries are sustained,' and where there is no privity."21

California recently has joined the $L a$ Hue and Chapman cases with the decision in Greenman v. Yuba Power Products, Inc., ${ }^{22}$ a case involving a breach of an express warranty. Greenman's wife purchased a "Shopsmith," an all purpose power tool, from a retailer. While using the "Shopsmith" as a lathe to turn a piece of wood, Greenman was injured when the piece suddenly flew out of the machine and struck him on the forehead. About ten and a half months later the husband gave written notice to both the retailer and the manufacturer that he claimed breaches of warranty, and he then filed a complaint against them alleging such breaches and negligence. Instructions were submitted to the jury for breach of implied warranties against the retailer, and breach of express warranties

15 Pritchard v. Liggett \& Myers Tobacco Co., 295 F.2d 292 (3d Cir. 1961); Hampton v. Gebhardt's Chili Powder Co., 294 F.2d 172 (9th Cir. 1961); Bonker v. Ingersoll Products Corp., 132 F. Supp. 5 (D. Mass. 1955) ; Title Ins. \& Trust Co. v. Affiliated Gas Equipment, Inc., 191 Cal. App. 2d 318, 12 Cal. Rptr. 729 (1961); Maecherlein v. Sealy Mattress Co., 145 Cal. App. 2d 275, 302 P.2d 331 (1956).

10 See note 14 supra.

1750 Wash. 2d 645, 314 P.2d 421 (1957).

18 Id. at 647,314 P.2d at 422. See 1 FruMer \& FrIEdacan, Products Liabicity 537-38 (1961); Prosser, The Assault Upon the Citadel (Strict Liability to the Consumer), 69 Yate L.J. 1099, 1131 (1960).

10 Compare text accompanying note 27 infra.

20198 F. Supp. 78 (D. Hawaii 1961), af'd, Brown v. Chapman, 304 F.2d 149 (9th Cir. 1962).

21 Id. at 85, quoting from 1 FrUMLER \& FrIEDMaN, Products LIABII'TY, \& 19.05 [1] at 537-38 (1960). The statement would seem to have little weight since the court of appeals in affirming the decision mentioned only the ground that notice was given within a reasonable tiune. Brown v. Chapman, 304 F.2d 149, 152 (9th Cir. 1962).

2259 A.C. 67, 377 P.2d 897, 27 Cal. Rptr. 697 (1963). A Connecticut lower court decision also recently dispensed with the notice requirement where there was no privity of contract hetween a manufacturer and an injured consumer. Ruderman v. Warner-Lambert Pharmaceutical Co., 23 Conn. Supp. 416, 184 A.2d 63 (1962). 
and negligence against the manufacturer..$^{23}$ Although the jury found in favor of the retailer, it returned a verdict against the manufacturer without specifying upon which count it based its decision. The manufacturer appealed, contending that the husband did not give notice of the breach within a reasonable time,${ }^{24}$ and that hence the court erred in liaving presented instructions on warranty to the jury. ${ }^{25}$ The California Supreme Court affirmed the judgment of the trial court, holding that no notice was required under the circumstances presented. The notice provision, however, was held to be inapplicable not because the parties were not "buyer" and "seller," but because an express warranty action where there is no privity is a product of the common law, for which the provisions of the Sales Act have no relevance. ${ }^{26}$

The court in Greenman did not foreclose the requirement of seasonable notice solely on the narrow ground just stated, but rather went on to consider the possibility of requiring notice in warranty actions apart from the requirements of the Sales Act. The court noted that in prior decisions in which privity has been circumvented, Cahifornia courts have applied Sales Act definitions to common law warranties "because they provide appropriate standards for the court to adopt under the circumstances." 27 Therefore, the substance of the notice statute could have been held applicable if it were deemed to represent a fair measure of legislative policy regarding actions brought under a common law express warranty. ${ }^{28}$ In rejecting this possibility, however, the court did not consider the question inerely within the narrow scope of express warranty. Instead, it rejected

23 At trial evidence was presented that the husband had read a brochure prepared by the manufacturer relating to the tool's rugged construction. He also introduced substantial evidence that the tool's defective design and construction caused his injuries. 57 A.C. at 69-70, 377 P.2d at 898-99, 27 Cal. Rptr. at 698-99.

24 The Uniform Sales Act is currently the law in California. CAL. Crv. Code $\$ 1769$.

25 Both parties assumed that the Sales Act provisions were applicable. The only question argued on appeal from the trial court was whether the plaintiff had complied with the requirements of the notice section. Brief for Appellant in the District Court of Appeals; Brief for Respondent in the District Court of Appeals.

26 By basing the liability upon a counmon law cause of action, the court has avoided the fictitious methods that many courts bave utilized to circumvent the privity requirement of the Sales Act. See note 15 supra. Previous California decisions, however, provide weak support for such a position. The court cited five cases to show that California courts have recognized that warranties exist in the common law. Of these, two cases dealt not with defective chattels, but with misrepresentation in employment contracts. Souza \& McCue Constr. Co. v. Superior Court, 57 Cal. 2d 508, 370 P.2d 338, 20 Cal. Rptr. 634 (1962); Gagne v. Bertran, $43 \mathrm{Cal}$. 2d 481, 275 P.2d 15 (1954). Of the remaining three, one case held that in adopting the Sales Act the legislature intended that the implied warranties provision should inure to the benefit of ultimate consumers of foodstuffs. Klein v. Duchess Sandwich Co., 14 Cal. 2d 272, 283, 93 P.2d 799, 805 (1939). Another held an employee of the purchaser-employer to be in privity with the seller, and specifically granted relief under the Sales Act. Peterson v. Lamb Rubber Co., 54 Cal. 2d 339, 348, 353 P.2d 575, 581, 5 Cal. Rptr. 863, 869 (1960). The remaining case adopted in dictum the Sales Act definition of express warranty, although there was no privity, and gave no indication that recovery would not have been under the Sales Act. Burr v. Sherwin Williams Co., 42 Cal. 2d 682, 696, 269 P.2d 1040, 1049 (1954). One California lower court case has found an express warranty with apparently no reliance upon the provisions of the Sales Act. Free v. Sluss, 87 Cal. App. 2d 933, 197 P.2d 854 (San Diego Super. Ct. 1948).

2759 A.C. at 71, 377 P.2d at 899-900, 27 Cal. Rptr. at 699-700. But see cases discussed in note 26 sucpra.

${ }^{28}$ See Clinkscales v. Carver, 22 Cal. 2d 72, 75, 136 P.2d 777, 778 (1943); Dana v. Sutton Motor Sales, 56 Cal. 2d 284, 287, 363 P.2d 881, 883, 14 Cal. Rptr. 649, 651 (1961). 
the notice requirement in such broad language as to imply that it intended to preclude the necessity for notice in any action in which an injured consumer and defendant manufacturer are not in privity. ${ }^{29}$

Two justifications were presented in support of this blanket treatment of notice as an mappropriate standard. First, the court adopted the "rule" of $L a H u e$ v. Coca Cola Bottling, Inc. ${ }^{30}$ and Chapman v. Brozen ${ }^{31}$ as authority for the proposition that the notice requirement is not an appropriate policy measure "in actions by injured consumers against manufacturers with whom they have not dealt."32 As previously mentioned, the notice requirement was disposed of in La Hue because the parties did not fit within the strict definition of the statute. The court in $L a$ Hue did not consider the question whether the notice provision should be extended beyond the scope of the Sales Act. The Chapman case also would appear to be weak support for such an important proposition. Although the lower court in Chapman apparently would have rejected the notice requirement as a matter of policy, the statement at best was only an alternative holding and was not considered in the appellate decision. ${ }^{33}$

Second, the court reasoned that when notice is required in a personal injury action against a remote seller it becomes a " booby-trap for the unwary [consumer]. " 34 Such a position has considerable merit. A person injured by defective goods is normally far removed from the manufacturer as a result of the great breadth of modern day marketing systems. In some instances neither the identity of the manufacturer nor his location are readily available to the injured consumer; and, as the court pointed out, " at least until [the consumer] las had legal advice it will not occur to him to give notice to one with whom he has had no dealings." "35 Also, the manufacturer is the one who has normally created the defect that has caused the injury, and it would be undesirable to allow him to escape liability for a valid claim merely because notice was belated or improperly pleaded.

The court, however, did not discuss policy considerations that support the judicial adoption of a notice requirement. First, the manufacturer deserves early warning as a protection against belated claims. ${ }^{36}$ Althougl the consumer bears the burden of proving the breach of warranty, the manufacturer is leeld strictly liable. Thus, his only defense will often rest upon an early investigation of the circumstances surroundiug the possible breach while the evidence is still fresh. ${ }^{37}$ Since in most instances the manufacturer will have no knowledge of the alleged breach, notice may be justified as a method of providing this warning. Second, notice serves as a protection to the public agamst further injury. Once the manufacturer has notice, he may examine his goods to determine the nature and extent

29 "The notice requirement of section 1769 , however, is not an appropriate one for the court to adopt in actions by injured consumers against manufacturers with whom they have not dealt." 59 A.C. at 71, 377 P.2d at 900, 27 Cal. Rptr. at 700.

3050 Wash. 2d 645, 314 P.2d 421 (1957).

31198 F. Supp. 78 (D. Hawaii 1961).

3259 A.C. at 71,377 P.2d at 900,27 Cal. Rptr. at 700.

33 See note 21 supra.

3459 A.C. at 71, 377 P.2d at 900, 27 Cal. Rptr. at 700, quoting from Prosser, supra note 18 at 1130 .

35 Ibid.

30 See Mead v. Coca-Cola Bottling Co., 329 Mass. 440, 443, 108 N.E.2d 757, 759 (1952).

37 See United States v. Whitin Mach. Works, 79 F. Supp. 351, 358 (D. Mass. 1948), rev'd on other grounds, 175 F.2d 504 (1st Cir. 1949). 
of the defect. If the manufacturer finds that the product or an identifiable group of items are defective, he can cease or modify further production, have the faulty goods removed from the chain of distribution, and possibly alert consumers who have already purchased defective goods. ${ }^{38}$

The force of the foregoing arguments in support of a notice requirement is lessened by the variable of "reasonable time." As the time allowed the consumer to give notice increases, the benefit to the manufacturer and the public diminishes. After a period of months much of the evidence surrounding the breach has likely been lost, and the manufacturer no longer has an opportunity to retrieve the defective goods. In previous cases imvolving personal injury actions between contracting parties, the courts have been quite liberal in defining a "reasonable time." 39 Where the litigation involves a manufacturer and remote consumer, the circumstances would normally dictate an even broader interpretation. ${ }^{40}$ This uncertain benefit to the manufacturer coupled with the hardship to the "unwary consumer" appears to justify the court's decision to dispense with the notice requirement.

Although the decision dealt specifically with the notice question, the court went on to articulate a broader rationale as to the nature of the manufacturer's hability. On alternative grounds the court held there was no need to plead an express warranty because a "manufacturer is strictly liable in tort when an article he places on the market, knowing that it is to be used without inspection for defects, proves to have a defect that causes injury to a human being." 41 This language appears to foretell a sharp break in future cases from past California decisions which uniformly adopted Sales Act definitions of warranty, and then circumvented the privity requirement by various inethods. ${ }^{42}$ If strict liability under this form of action is to be couched in terms of warranty at all, it will apparently be a warranty direct from the manufacturer to the consumer, and will arise as a matter of tort policy. ${ }^{43}$ Greenman may very well become Dean Prosser's "standard bearer" in the final "assault upon the citadel" of privity, ${ }^{44}$ but a full discussion of that topic is beyond the scope of this Comment. Although no reference was made to the applicability of notice with regard to the alternative ground, it seems certam that the supreme court will reject any attempt to engraft such a requirement on to this form of liability. As discussed previously, the court treated its rejection of notice as applicable to any actions between injured remote consumers and inanufacturers, and not as a mere refusal to apply a notice require-

38 The effectiveness of such a protection may be questionable because of the difficulty and cost in locating the goods in today's mass marketing systems. See 15 STAN. L. REV. 381, 387 (1963).

${ }^{39}$ See cases cited note 13 supra.

40 See Hampton v. Gebhardt's Chili Powder Co., 294 F.2d 172 (9th Cir. 1961), in which five months was held to be a reasonable time under California law. Moreover, the court favored the remote consumer by allowing him to file a supplemental complaint to cure his failure to give notice before commencement of the action.

4159 A.C. at 72,377 P.2d at 900, 27 Cal. Rptr. at 700.

42 See text accompanying note 27 supra.

${ }^{43}$ In strict hability, instead of establishing a manufacturer's liability under Sales Act definitions of warranty, the plaintiff must merely prove "that he was injured while using the [product] .... in a way it was intended to be used as a result of a defect in design and manufacture of which plaintiff was not aware that made the [product] ... unsafe for its intended use." 59 A.C. at 74, 27 Cal. Rptr. at 701, 377 P.2d at 901, 27 Cal. Rptr. at 701.

44 See Prosser, supra note 18. 
ment in a common law express warranty action. ${ }^{45}$ Therefore, even for liability wholly in tort rather than warranty, there appears to be no possibility for a notice requirement.

Since Cahiforma courts have relaxed the requirement of privity in certain warranty actions agamst the retailer, ${ }^{46}$ the Greenman decision raises uncertainties concerning the future of the notice requirement with regard to the retailer. In an action by an injured non-buyer against the retailer, the Sales.Act warranties are technically not applicable as the plaintiff is not a "buyer" within the meaning of the act. ${ }^{47}$ Therefore, the Cahifornia courts again will have to determine whether the statutory notice provision is an "appropriate [standard] . . . for the court to adopt under the circumstances presented." 48 While the retailer may have no greater need for notice as a protection against belated claims than does the manufacturer, the reasons for disposing of the requirement appear less forceful in the case of the retailer. Although the parties are not in privity, the injured non-buyer will normally be in close proximity to the actual buyer who could easily inform him of the seller's identity. In inost instances the seller also will be near at hand. Also, the manufacturer, not the retailer, is usually the culpable party. Quite often the retailer's greatest sin is the mere displaying of a sealed package which subsequently proves to contain a defective product. ${ }^{49}$ Therefore, unless there is a general disfavor for any notice requirement where personal injury is suffered, which probably is not the case in Cahforma, ${ }^{50}$ there would seem to be no compelling reason not to provide the retailer with the protection of seasonable notice. If the unusual situation occurs where either the identity of the retailer or his location is not immediately known, then the "reasonable time" could properly be extended under the special circumstances.

\section{II}

NOTICE UNDER THE UNIFORM COMMERCIAI CODE

The Uniform Commercial Code, recently enacted in more than one-third of the states, ${ }^{\mathrm{bI}}$ will likely govern much of the future litigation concerning the notice

45 See text accompanying note 29 supra.

46 Klein v. Duchess Sandwich Co., 14 Cal. 2d 272, 93 P.2d 799 (1939); Jensen v. Berris, 31 Cal. App. 2d 537, 88 P.2d 220 (1939).

47 See note 3 supra. This would appear to be the present position of the California courts. "[The Uniform Sales Act] . . . deals with the rights of parties to a contract of sale or sale." Greenman v. Yuba Power Products, Inc., 59 A.C. 67, 71, 377 P.2d 897, 899, 27 Cal. Rptr. 697, 699 (1963). In Greenman, however, the court was concerned only with an action against a manufacturer. It is arguable that the basis for holding the provisions of the Sales Act inapplicable was because the manufacturer was the producer of the goods, not because he was not the immediate seller. In future actions against either the retailer or wholesaler, whose only functions concern the selling of the goods, the courts possibly may extend the definitions of "buyer" and "seller" and hold the notice provision of the Sales Act applicable.

48 See text accompanying note 28 supra.

49 E.g., Klein v. Duchess Sandwich Co., 14 Cal. 2d 272, 93 P.2d 799 (1939).

50 Vogel v. Thirfty Drug Co., 43 Cal. 2d 184, 272 P.2d 1 (1954); Whitfield v. Jessup, 31 Cal. 2d 826, 193 P.2d 1 (1948); Maecherlein v. Sealy Mattress Co., 145 Cal. App. 2d 275, 302 P.2d 331 (1956).

61 Alaska, Arkansas, Connecticut, Georgia, Tllinois, Kentucky, Massachussets, Michigan (effective Jan. 1, 1964), New Hampshire, New Jersey, New Mexico, New York (effective Sept. 
requirement. Although section 2-607, the notice provision of the Code, is similar in content to that of the Sales Act, ${ }^{52}$ the Code contains a built-in extension of privity that may have a considerable effect upon courts' interpretations of the notice section. Section 2-318 provides that "a seller's warranty whether express or implied extends to any natural person who is in the family or household of his buyer or who is a guest in his home if it is reasonable to expect that such person may use, consume or be affected by the goods and who is injured in person by breach of the warranty." 53 The Official Code Comment to section 2-607 states that the "reason of the notice section" applies to an action brouglit by one of these enumerated beneficiaries against the immediate seller. ${ }^{54}$ Thus, the draftsmen of the Code evidently felt that the word "buyer," contained in section $2-607$, is not to be strictly construed, at least where recovery is possible under section 2-318. Many courts quite probably will derive a legislative intent from this Code Comment and require that notice be given by those persons included under section $2-318 . .^{55}$ On the other hand, the Code Comment is by no means akin to a legislative enactment, ${ }^{56}$ and there are indications that some courts may refuse to follow this extension of notice..$^{57}$

The text of section 2-318 refers only to actions brought by certain beneficiaries of the buyer against the retailer. The Comment to section 2-318 indicates that the Code is "neutral" in regard to the extension of a seller's warranties to those parties who are not in privity with the seller, but are within the cliain of distribution (which chain would include the manufacturer, distributor, retailer,

27, 1964), Ohio, Oklahoma, Oregon (effective Sept. 1, 1963), Pennsylvania, Rhode Island, and Wyoming have enacted the Uniform Comnercial Code. 1 ANDERson, ANDERson's UNIFORM Comomercial Code (Supp. 1962, at 5-54). On June 8, 1963, California enacted the Code, Cax. Star. ch. 819, $\$ 1$ (1963), but it will not become effective until January 1, 1965, Car. STat. ch. $819, \S 52$ (1963).

52 See note 1 supra. The word "notify" las been substituted by the Code for "give notice" to enphasize that "the essential fact is the proper dispatch of the notice, not its receipt." UNIFORA COMOMERCIAL CODE \$ 1-201, comment 26.

53 UNIFORM COMOMERCIAL CODE \$ 2-318.

54 UNIFORM COMOMERCTAI CODE \$ 2-607, comment 5.

55 Cases decided under the Code have treated the Comments as indicative of legislative intent. Thompson v. Reedman, 199 F. Supp. 120, 121 (E.D. Pa. 1961) ; Hochgertel v. Canada Dry Corp., 409 Pa. 610, 187 A.2d 575 (1963); Kaczmarkieicz v. J. A. Williams Co., 13 Pa. D. \& C.2d 14, 15 (1957). The Comment is also cited with approval in Pritchard v. Liggett \& Myers Tobacco Co., 295 F.2d 292, 298 n.16 (3d Cir. 1961), a ease decided under the Sales Act.

56 "Surely the Conments may be given at least as much weiglit as an able article or treatise construing the Code. It is equally clear that the Conments do not approach the weight of legislation; if the statutory provisions adopted by the legislature contradict or fail to support the Comments, the Coniments must be rejected." Honnord, Cases on Sares and Sales Financing 19 (2d ed. 1962).

57 In an unreported case a Massachussets court imphed that a beneficiary under section 2-318 of the Code might not be required to give notice to the seller in an action for breach of warranty. The case seems only to hold that insufficient notice from the buyer may be held adequate if given by a beneficiary. Menard v. Great Atl. \& Pac. Tea Co., No. T-584 App. Div. Central Dist. Ct. of Worchester, Note, 47 Mass L.Q. 190 (1962).

In a study of the Conmercial Code the New York Law Revision Commission noted that "Comment 5 to Section 2-607 says that a third party beneficiary is required to give the seller notice that an injury has occurred. Neither section 2-318, nor Section 2-607 expressly imposes such an obligation." N.Y. LAW REvision COMMM'N STUDY OF THE UNTFORM COMMERCIAL CODE 709 (1955). 
and consumer-purchaser).$^{58}$ The scope of the extension, if any, is to be governed by "developing case law." 59 Although the Coment makes no mention of persons who are neither included in section 2-318 nor within the distributive chain, decisions under Pennsylvania law have assumed that the section is neutral with respect to these persons. ${ }^{60}$ Therefore, section 2-318 possibly will not restrict the "developing case law" in any judicial inquiry into the privity question.

Judicial treatment of the notice requirement will probably depend upon the manner in which "developing case law" dispenses with the necessity of privity. ${ }^{61}$ If courts treat the liability as a product of the common law or public policy, the provisions of the Code, including the notice section, will not be applicable. ${ }^{62}$ In these jurisdictions the question of notice will be considered, if at all, as in Greenman: whether a notice requirement is an appropriate standard to be adopted by the courts irrespective of the Code. ${ }^{63}$ On the other hand, many courts will probably provide a Code recovery by merely straining or ignoring the wording of the warranty sections. ${ }^{64}$ Since the sections of the Code will be applicable in such jurisdictions, the fate of the notice requirement will be determined by the judicial construction accorded to the words "buyer" and "seller" contained in section 2-607. In cases involving injured non-buyers not in privity with the immediate seller, the courts may well derive from the Comment to section 2-607 a legislative intent that "buyer" is to be liberally construed in all warranty actions under the Code. The task becomes more difficult when the defendant is the manufacturer or wholesaler, for the Comment is silent in regard to any extension of "seller." 65 The courts apparently will be forced to weigh the various policy considerations of the notice requirement and treat their determination as dispositive of the legislative intent.

After the Greenman decision, the California legislature enacted the Uniform Commercial Code which is to become effective on January $1,1965 .{ }^{86}$ Although the legislature accepted verbatim the notice section, ${ }^{67}$ it took a unique position by

58 Untrorar Comarercial Code \& 2-318, comment 3.

bo Ibid.

80 Thompson v. Reedman, 199 F. Supp. 120, 121 (E.D. Pa. 1961) ; Hochgertel v. Canada Dry Corp., $409 \mathrm{~Pa} .610,187$ A.2d 575 (1963). But see Ezer, The Impact of the Uniform Commercial Code on the California Law of Sales Warranties, 8 U.C.L.A.L. REv. 281, 332 (1961); 50 GEo. L.J. 626, 630 (1962).

61 Irrespective of the manner in which the courts dispose of the privity requirement, they may possibly ignore the incongruity of the wording of the notice section and merely assume that notice is necessary. E.g., Pritchard v. Liggett \& Myers Tobacco Co., 295 F.2d 292 (3d Cir. 1961). It is doubtful, however, that plaintiffs' attorneys will allow such a condition to exist. They will surely present the arguments of Greenman and LaHue and force a decision of the notice question.

62 See note 26 supra.

63 See text accompanying note 27 supra.

64 See nofe 14 supra. One state, Wyoming, has provided for a Code recovery by modifying section 2-318. Wyoming's enactment extends the benefit of "a seller's warranty whether express or implied ... to any person who may reasonably be expected to use, consume, or be affected by the goods and who is injured by breach of the warranty." WYo. STar. ANN. \& 40A-2-318 (Supp. 1961). Since the manufacturer, wholesaler, and retailer are all "sellers" in some phase of the chain of distribution, all recovery apparently will be possible under this statute.

65 See note 47 supra.

o6 Cad. Stat. ch. 819, $\$ 1$ (1963) (effective Jan. 1, 1965).

67 CaI. Stat. ch. 189, § 1, para. 2607 (1963) (effective Jan. 1, 1965). 
deleting section 2-318 from the act. The purpose of the deletion apparently was to insure that previous California decisions, which had gone beyond the scope of the section, would not be contracted or overruled. ${ }^{88}$ By removing the extended coverage from the act, the legislature has apparently recognized that a liability exists beyond the provisions of the Code and that its limits will be governed by the courts.

Thus, the Greenman holding of common law warranty is impliedly strengthened by the enactinent of the Code. Since the notice section of the Code has no relevance to such actions, the possibility of a notice requirement to benefit the manufacturer is surely foreclosed by the broad policy determination of Greenman. Moreover, because of the deletion of section 2-318, the question of notice to the retailer from the injured non-buyer will also likely be decided as a matter of policy by the courts.

Donald P. Newell

68 In the original Senate Preprint Bill No. 1, section 2-318 was included. SENATE FACT Finding Conomittee on the Judictary, Sixth Progress Report to the Legrstature, Part 1, The UnIForma Commerctal Code 160-61 (1959-61).

The Final Report of the Subcommittee on Chapter 2 (Sales) of the Umiform Commercial Code expressed a divided opinion on section 2-318, and recommended that "additional consideration to be given to this section to determine the lengths to which its codification should go." Id. at 340.

Because of the length and complexity of proposed amendments to the original bill, Professors Marsh and Warren were retained to analyze various sections of the Code, including section 2-318. Their report showed that California decisions, Klein v. Duchess Sandwich Co., 14 Cal. 2d 272, 93 P.2d 799 (1939), and Peterson v. Lamb Rubber Co., 54 Cal. 2d 339, 353 P.2d 575, 5 Cal. Rptr. 863 (1960), had already gone beyond the terms of scction 2-318. Therefore, they recommended that section 2-318 not be enacted as it represented a "step backward." Id. at 457-58. As a result of this report, section 2-318 was deleted in Senate Bill No. 1093, as amended May 4, 1961. Id. at 676. Subsequent amendments had no effect on section 2-318; it was deleted froin the act as passed on June 8, 1963. 